\title{
ILLÓ ÉS NÖVÉNYI OLAJAK ALKALMAZÁSA, MINT LEHETSÉGES LÁGYÍTÓSZEREK KÜLÖNBÖZŐ ELASZTOMER TEXTÚRÁKBAN
}

\author{
Tamási Kinga - Zsoldos Gabriella
}

\begin{abstract}
Absztrakt: A lágyítók csoportjába azok az anyagok tartoznak, amelyeket a keménység csökkentése, a nyújthatóság és a feldolgozhatóság javítása érdekében adagolnak a műanyagokhoz. A lágyító hatású anyagokra az a jellemző, hogy csökkentik a polimerek megömlési hőmérsékletét, rugalmassági modulusát és ridegségi hőmérsékletét, de nem változtatják meg a makromolekulák kémiai természetét. A fenntarthatóság jegyében és a müanyagokkal szemben táplált társadalmi ellenérzések enyhítése érdekében napjainkban egyre több figyelmet kapnak az ún. természetes eredetü lágyítószerek fejlesztése, alkalmazhatóságuk vizsgálata. Ezért munkánk során repceolaj alapú gumiipari lágyítószert vizsgáltunk különbözö vizsgálati módszerekkel.

Abstract: The plasticizers are a group of materials which are decrease the hardness, increase the extensibility and processability. Plasticizers increase the melting temperature, elasticity and the frigidity temperature, but do not change the chemical behaviour of macromolecules. Nowadays the natural additives are in the focus on the market, because some of the current plasticizers (e.g: phtalateesters) has carcinogenic, teratogenic and mutagenic effect to the human health. Because of that our research main point was to examine the effect of rapeseed oil in the natural rubber texture.
\end{abstract}

Kulcsszavak: lágyító adalék; ftálsav-észterek; gumik; növényi olajok; egészségvédelem

Keywords: plasticizers; phtalate-esters; rubbers; plant oils; health protection

\section{Bevezetés}

A rideg, hỏre lágyuló mủanyagok elasztomerekkel vagy más lágy polimerekkel való módosítása rendkívül sok lehetőséget rejt magában. Napjaink lágyítóválasztékában dominálnak a ftálsav-észterek és anhidridek, adipátok, citrátok és a policiklusos aromás vegyületek is. Lényegében ezek fedezik a foglalkozó ágazat lágyítószükségletét. Elterjedésüket müszaki alkalmasságuk mellett kedvező áruk is elösegítette, amiben a ftálsav-észter típusú lágyítóknak is nagy szerepe volt. Példának okáért a PVC-hez használt lágyítók mennyiségének $85 \%$-át ma is a ftalátok teszik ki, annak ellenére, hogy a szigorodó környezetvédelmi, munkaegészségügyi, élelmiszer-higiéniás szabályok miatt aggályok merültek fel a használatukkal kapcsolatban. Ezek az ellenérzések alapozták meg kutatásainkat a természetes alapú lágyítószerek irányába, amely során számos különböző növényi olaj viselkedését ellenőriztük nyers kaucsuk alapanyagokban.

\section{Anyagok és módszerek}

Az alap és adalékanyagok kiválasztása, a minta elökészítés egyik legfontosabb folyamata a munka során. Minden esetben az elasztomer mátrix nyers kaucsuk volt, amelybe repceolaj kerül bekeverésre. 


\subsection{A nyers kaucsuk ismertetése}

A legkiválóbb tulajdonságokkal a természetes kaucsuk rendelkezik, a világon összesen gyártott mennyiség mintegy felét a egymagában adja, a másik felét az összes múkaucsuk együttvéve. A természetes kaucsuk alapvetően ciszpoliizoprénből áll, melyben szabályosan, ugyanabban a helyzetben követik egymást az ismétlődő szakaszok. Ez viszonylag nagy rendezettséget eredményez. Ugyanakkor a természetes kaucsuk mindig tartalmaz fehérjetermészetű anyagokat, amelyekben vannak poláros csoportok, ezeknek a kutatások során még nagy jelentősége lehet a későbbi összeférhetőségi vizsgálatoknál. Ezek között erős a kölcsönhatás, az átlagnál jobban kristályosodnak különösen húzóigénybevétel (a makromolekulák orientálódása) hatására. Ezért a töltőanyagot nem tartalmazó guminak is nagy a szakítószilárdsága (300 MPa), és aktív töltőanyaggal ez még tovább javítható.

\section{1. ábra: A nyers kaucsuk (1,4,-cisz-poliizoprén) szerkezeti képlete és makromolekuláris szerkezete}

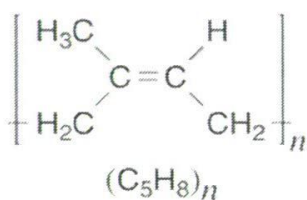

$\left(\mathrm{C}_{5} \mathrm{H}_{8}\right)_{n}$



$$
\text { 政 }
$$

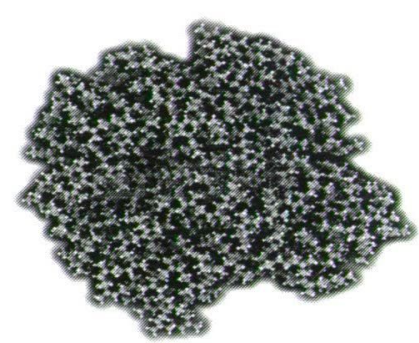

Forrás: http://www.tutorvista.com/content/chemistry/chemistry-ii/carbon-compounds/naturalrubber.php(2017.)

A természetes kaucsukból készült gumi nagyon jó dinamikus tulajdonságokkal rendelkezik, hiszterézise kicsi, és kopásállósága szintén jó. A vulkanizálatlan kaucsuk nyersszilárdsága és nyújthatósága nagy. Kedvező a tapadási tulajdonsága, amely a nyersszilárdsággal együtt fontos tényező a gumiabroncsok gyártása során, emiatt a természetes kaucsuk jó alapanyaga az abroncsgyártásnak. Keverési, alakítási eljárásokban, mint az extrudálás és kalanderezés kedvező tulajdonságokat mutat. További előnye a magas vulkanizálási arány. Hủtés és temperálás után a kaucsuk $10^{\circ} \mathrm{C}$ és $-35^{\circ} \mathrm{C}$ között opálossá és rugalmatlanná válik, ezt a részleges kristályosodási folyamat okozza, illetve nyújtó terhelés hatására is bekövetkezik a kaucsuk kristályosodása. Ez növelö hatással bír, mind a nyers kaucsuk, mind a vulkanizátum nyersszilárdságára, húzószilárdságára.

A nyers kaucsuk szerves oldószerekben, benzolban, petroléterben, széntetrakloridban (CCl4), valamint kőolajban oldódik, illetve erősen duzzad. A vulkanizált kaucsuk csak duzzadásra hajlamos, mert a térháló megakadályozza a polimer felbomlását. Strukturális stabilitása nagy, rugalmassága és hideg hőmérsékleti rugalmassága, dinamikus tulajdonságai kiválóak, rugalmassági modulusza (merevsége) nagy, de kopásállósága közepes. Öregedésállósága (UV) és 
ózonállósága a polimer láncban található telítetlen kötések miatt gyenge, de ezek telítésével, stabilizátorok vagy antioxidánsok alkalmazásával javítható. Fény hatására bekövetkezhet a polimer gyorsabb degradációja, bomlása, ezért kell fénymentes helyen tárolni.

\subsection{Lágyító adalékok és a repceolaj ismertetése}

\subsubsection{A lágyító adalékokról általánosan}

A minőségi követelmények a lágyítók tisztaságára, feldolgozás közbeni viselkedésükre és azokra a jellegzetes tulajdonságokra vonatkoznak, amelyekkel a plasztomerek tulajdonságait alakítják. Az iparban használatos lágyítók túlnyomóan kis vagy nagy viszkozitású folyadékok, ritkábban szilárd termékek. Általános követelmény a nagy tisztaság, színtelenség, a semlegesség, a szag- és íztelenség, valamint az anyag egységes összetétele.

Sok hőre lágyuló műanyag nagy feldolgozási hőmérsékletet igényel (akár 100 és $180^{\circ} \mathrm{C}$ között), ezért az elszíneződés és a bomlás elkerülése végett a lágyítóknak jó hőstabilitással kell rendelkezniük. A kis illékonyság több szempontból előnyös. Egyrészt feldolgozás közben kevesebb a kellemetlen gőz, másrészt az öregedésállóság jobb, különösen akkor, ha a lágyított rendszereket a használat során időnként erősebb hőterhelés éri. Az időjárás összetett hatásaival szemben ellenálló termékek gyártásánál a kis illékonyság mellett fontos még a fényállóság, a vízextrakcióval és a gombásodással szembeni ellenálló képesség, valamint a hidegállóság is (Angyal, 2012). A lágyítószerek feladata tehát, hogy a polimerömledék visszahütése után ne alakuljon vissza a szoros szerkezet, tartalmazzon lágyabb szegmenseket az üvegesedési hőmérséklet felett is. A megfelelő mennyiségben (10-25 tömegrész) alkalmazott lágyító molekulái a polimer láncok közé kerülve csökkentik a kölcsönhatásukat, ezáltal növelve a rugalmasságukat. Érdemes tehát az alappolimerhez képest kisebb moláris tömegü lágyítószert választani a megfelelő kémiai-fizikai tulajdonságok figyelembe vételével (lásd: 2. ábra).

\section{2. ábra: A lágyító adalékok múködési mechanizmusa}



Forrás: A szerző saját szerkesztése (2017.) 
A lágyító adalékok az alappolimerrel extruderen, keverő hengerszéken, fröccsgépen feldolgozhatók, valamint szinterező anyagként is használhatók. Füthető gyúrókamrákban gyakorlatilag minden hőre lágyuló mủanyag és elasztomer összedolgozható jelen esetben $10 \%$-os frikcióval történt a próbatestek előállítása.

\subsubsection{A repceolaj ismertetése}

A repceolaj, másnéven canola-olaj, a repce növény magjából készült növényi zsiradék, mely sötét színű és jellegzetes aromája van. Kénsavval való finomítás után sárga színủ, majdnem szagtalan. A repceolaj fő technológiai felhasználási területe a biodízel előállítás. A kedvező élettani hatások eléréséhez a különböző vadrepce fajtákat keresztezik és nemesítik, ennek következtében a reformétkezés területén a kedvező Omega-3 zsírsav összetétele miatt fogyasztását javasolják. Továbbá a gyógyszeripari és kozmetikai felhasználása is jelentős. Finomítatlan változatából ipari kenőanyag készül (Bálint, 2012).

Fontos kémiai és fizikai tulajdonságai közül néhány jellemzőt érdemes megemlíteni, fajsúlya $0,913-0,918 \mathrm{~g} / \mathrm{cm}^{3},-6$ és $-10{ }^{\circ} \mathrm{C}$ között megfagy, alkoholban alig, éterben könnyen oldódik, nem szárad be.Fontos bioaktív anyagai a bétasitostanol $(0,925 \mathrm{mg} / 100 \mathrm{~g})$, campestanol $(0,811 \mathrm{mg} / 100 \mathrm{~g})$, delta-5 avenastrol $(11,721 \mathrm{mg} / 100 \mathrm{~g})$.

A nemesítetlen repceolaj változó mennyiségü (20-50\%) erukasavat (zsírsav) tartalmaz, amely a festékipar számára fontos összetevő. Ez az anyag táplálkozásra ebben a formában nem alkalmas, mivel rosszul emészthető, az izom- és májsejtekben lerakódva káros elváltozásokat okoz (Bálint, 2012.) Fontosabb zsírsavösszetételét az 1. táblázat szemlélteti:

\section{1. táblázat: A repceolaj irodalmi zsírsavösszetétele}

$\begin{array}{cccc}\text { Rövid jelölés } & \text { Triviális név } & \text { Család } & \text { Mennyiség [\%] } \\ 18: 1 & \text { olajsav } & \omega-9 \text {, telítetlen } & 61 \\ 18: 2 & \text { linolsav } & \omega \text {-6, telítetlen } & 21 \\ 18: 3 & \alpha \text {-linolénsav } & \omega \text {-3, telítetlen } & 9-11 \\ 16: 0 & \text { palmitinsav } & \text { telített } & 4 \\ 18: 0 & \text { sztearinsav } & \text { telített } & 2 \\ & \text { transz-zsírsav } & \text { telítetlen } & 4 \\ & \text { Forrás: A szerző saját szerkesztése (2017.) } & \\ \text { Jelenlegi hasznosítása különbözö konyhatechnikai célokra mind margarin, mind } \\ \text { olaj formájában, emellett hajtóanyagként - mint például repce-metil-észter (RME) } \\ \text { és kenőanyagként is } & \text { használható. Továbbá alkalmazható a festékgyártásban, }\end{array}$


oldószerként, tenzidként, a kozmetikai iparban, linóleum-gyártásban és takarmányként (Bokor, 1998).

\section{3. ábra: A repce növény és olaja}



Forrás: www.google.hu (2017.)

A természetes eredetủ (növényi) lágyítók általában a polimerrel jól összeférhető, kis viszkozitású, alacsony dermedéspontú, viszonylag kismolekulájú vegyületek. Emiatt illékonyságuk magasabb hőmérsékleteken viszonylag nagy, gyorsan elpárolognak a gumiból. Ebben az esetben azután fagyásgátló hatásuk is csökken, és amellett a vulkanizátumok keménysége is növekszik. Ennek kiküszöbölésére megfelelö kompromisszumot kell kötni a dermedési pont és az illékonyság között (Angyal, 2012).

Ilyenkor azt is megkívánjuk, hogy a lágyító ne oldódjék ki a gumiból, ne migráljon ki a felületre. Ezért az előbbiek analógiájára gyakran engedni kell a fagyásgátló hatásnak és a kioldási hajlamnak. A viszonylag gyenge hidegállóságú, poláris speciális kaucsukokban az észter és éter típusú vegyületek terjedtek el fagyásgátló lágyítóként (például az említett ftálsav-észterek). Az illékonyság és a kioldhatóság csökkentése céljából a kisebb molekulájú termékek mellett elterjedtek a többértékü alkoholok és többértékủ savak kondenzálásával előállított lágyító típusok, ezért a repceolaj zsírsavösszetétele alapján kijelenthető, hogy ez az anyag elméletben megfelel az elvárásoknak.

Mivel a legtöbb gumigyártmánynak jellegzetes gumiszaga van, ami bizonyos területeken kellemetlenné teheti felhasználásukat. Fokozott mértékben kell ilyen jelenséggel számolni bizonyos alap- és segédanyagok felhasználása esetén, így pl. a füstölt típusú természetes kaucsukok, továbbá peroxidos vulkanizáló-rendszerek, bizonyos hajtóanyagok, lágyítók alkalmazása esetén. Ezt kiküszöbölendő egyes müszaki gumicikkekben, közszükségleti termékekben illatosítóanyagokkal igyekeznek megszüntetni a kellemetlen szaghatást. Erre a célra föként aceto-fenont, ritkábban kumarint alkalmaznak, de ismertek növényi kivonatok, mint például az illóolajok. Vizsgálataink során meghatározott receptúra alapján készített repcével kezelt kaucsuk alapú gumikeverékeket vizsgáltunk különböző mérési módszerekkel (FT-IR; SEM illetve mechanikai berendezésekkel) ahol az olaj hatását elemeztük. 


\subsection{A repceolaj és a nyers kaucsuk összeférhetősége}

Utracki definíciója szerint polimer blendnek nevezzük legalább két polimer vagy kopolimer keverékét, amelyben mindegyik makromolekuláris komponens több mint $2 \mathrm{~m} / \mathrm{m} \%$-ban van jelen. A polimer blendek komponensei lehetnek lineáris, elágazó vagy térhálós szerkezetü polimerek, illetve kompozitok, amelyek nem kovalens kötéssel kapcsolódnak egymáshoz. Amennyiben az összekevert polimerek egyike a minor komponens, akkor az egyszerüen adaléknak is tekinthető. Ebben az esetben a repceolaj, mint minor komponens fog a késöbbiekben szerepelni, míg a kaucsuk egyértelmüen a magasabb moláris tömegü komponenst szolgáltatja. Általánosan polimer/polimer elegyedés nem létezik, ezt mindig egy úgynevezett elegyedési küszöb korlátozza, amelyet sok független változó, mint például az összetétel, a molekulatömeg, a hömérséklet, a nyomás befolyásolja.

A tényleges összeférhetőség legfontosabb jellemzője a termodinamikai stabilitás vagy egyensúlyi állapot. A rendszer termodinamikailag akkor stabil, ha a kialakulást a Gibbs-féle (vagy Helmholtz) szabadenergia csökkenése kíséri. A Gibbs-féle szabadenergia (G) az egyensúlyi állapot kialakulásáig csökken, majd ezt követően az idővel nem változik. Amikor a kölcsönhatás kialakul a két kiindulási komponens között, $\Delta \mathrm{Gm}$ (a keverés szabadenergiája) negatív lesz és összeférhető (Tóth-Tamási, 2016). A polimer keverékeknél megfigyelhető, hogy a keverék homogenitása a Gibbs-féle szabadenergiától, G-töl függ, így a keverés eredményeként:

$$
\Delta G=\Delta H-T \Delta S
$$

ahol $\Delta H[\mathrm{~J}]$ és $\Delta S[\mathrm{~J} / \mathrm{K}]$ a rendszer entalpia és entrópia változása a keverékben, illetve $\mathrm{T}$ az abszolút hömérséklet [K]. Egyensúlyban az egyik polimer homogén oldódása a másikban egy spontán folyamat, ha $\Delta \mathrm{G}<0$. Ezért a keverhetőség attól függ, hogy a két tényező ( $\Delta H$ és $\Delta S$ ) közül melyik van túlsúlyban.

A polimer lágyítók, amelyek molekuláris szinten vannak az olvadékban diszpergálva, a hütést követően a rideg mátrixban maradnak. A blokk vagy ojtott polimerek kis mennyisége molekuláris szinten diszpergálható a homopolimerhez hasonló ojtott vagy blokk vég- vagy oldallánchoz. Ezekben az esetekben fontos szempont a homogén terület mérete és nem a keveredési hö, azaz a kritérium kinetikus és nem termodinamikai, míg az egyensúly be nem áll (Szakács, 2012). A polimerek elegyíthetősége jól megjósolható oldatuk egy közös oldószerben történő stabilizálásával. Elméletileg a keverhetőség molekuláris szinten értendő. Gyakorlati szempontból azonban az elegyedő polimerek mikroheterogén anyagok. Azt, hogy két polimer egymással nem elegyedő, részben vagy teljesen elegyedő, azt a fázisszerkezet határozza meg. Az egymással elegyedő keverékek optikai átláthatóssággal, homogenitással jellemezhetőek 50-100 Å szinten.

A polimerek korlátlan kölcsönös oldhatósága kivételes, szigorú körülmények között érhető el, például polivinil-klorid és butadién-nitril gumi, vagy polivinilacetát és cellulóz-nitrát esetében. Az megállapítható, hogy minél közelebb van két polimer oldhatósági paramétere vagy minél nagyobb a közöttük fellépỏ lehetséges kölcsönhatás ereje, annál nagyobb a valószínúsége, hogy összeférhetöek. Ez a jelenség vizsgálható a kölcsönhatási paraméterek kritikus értékein $\left(\chi_{\text {Crit }}\right)$, valamint a 
„,nem hidrogénkötéses oldhatósági paraméterek” felső határainak különbségén $(\Delta \delta)$ keresztül is (Szakács, 2012). Előzetes számításaink alapján kijelenthető, hogy a repceolaj és nyers kaucsuk az összeférhető tartományba kerültek.

\section{A próbatestek előkészítése}

A gumitermékek gyakran összetett termékek, melyek gumin kívül egyéb adalékanyagokat is tartalmaznak. Ezzel összefüggésben gumigyártásnak nevezzük általában azoknak a késztermékeknek az elöállítási folyamatát, amelyek számottevő mennyiségben tartalmaznak gumit (esetleg más anyagok mellett), amely folyamatot a 4. ábra szemléltet (Tóth-Tamási, 2016):

\section{4. ábra: A gumigyártás folyamata}

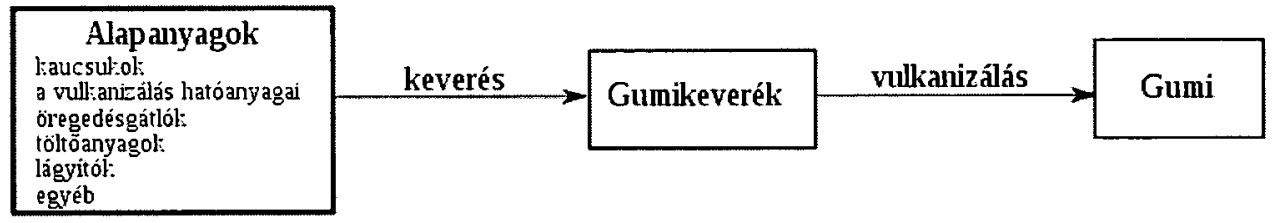

Forrás: www.wikipedia.hu (2017.)

\subsection{A bemérés és keverékkészítés}

A keverékkészítés első és meghatározó lépése a bemérés, amelyet megadott receptúra alapján végeztünk, analitikai pontossággal. Mivel munkánk célja a repceolaj adalék hatásának vizsgálata volt, a gumikeverékek során felhasznált egyéb anyagok pedig a következök voltak adagolási sorrendben, de a teljesség igénye nélkül:

1. Nyers kaucsuk / gumi $\left(\mathrm{C}_{5} \mathrm{H}_{8}\right)_{\mathrm{n}}$, mint alapanyag,

2. Sztearinsav $\left(\mathrm{C}_{18} \mathrm{H}_{36} \mathrm{O}_{2}\right)$, mint stabilizátor,

3. Korom $\left({ }^{14} \mathrm{C}\right)$, mint töltöanyag,

4. Cink-oxid ( $\mathrm{ZnO})$, mint aktivátor,

5. ALTAX $^{\circledR}$, mint gyorsítószer,

6. Kén $\left({ }^{32} \mathrm{~S}\right)$, mint térhálósítószer,

7. Repceolaj, mint lágyítószer.

Összesen három próbatest készült, egy kezeletlen és kettő eltérő korom összetételü. Mindhárom minta alapja $168 \mathrm{~g}$ nyers kaucsuk volt, a Minta1. és Minta2.-nél lágyítószerként már repceolajat alkalmaztunk, 60 g-ot, ebből 1 csepp repce olaj tömege átlagosan $0,02 \mathrm{~g}$ volt. A keverési eljárás az ASTM D3192 szabvány alapján történt. A vizsgálatokat szobahömérsékletü $\left(\mathrm{T}=20 \pm 1^{\circ} \mathrm{C}\right)$ és relatív páratartalmú $(50 \% \pm 1 \%)$ környezetben végeztük (lásd 2. táblázat), ugyanis a mikroklíma, illetve az adalékok megváltoztatási paraméterei befolyásolhatják a mérési eredményeket. A kaucsuk alapanyag aprítását nehezítette, hogy csak az erre a célra használatos elömelegített vágószerszámmal lehetett a tömböt darabolni. 
2. táblázat: A keverékkészítés folyamata és ideje

\begin{tabular}{|c|c|c|c|c|c|c|}
\hline \multicolumn{7}{|c|}{ Gumikeverékek előállításának folyamata } \\
\hline $\begin{array}{c}\text { Felhasznált } \\
\text { anyagok }\end{array}$ & \multicolumn{3}{|c|}{ Bemért mennyiségek/minta } & \multicolumn{3}{|c|}{ Keverékek előállítási folyamatának ideje } \\
\hline Adalékanyag neve & $\begin{array}{c}\text { Kaucsuk } \\
\text { Igumi }\end{array}$ & 1. minta & 2. minta & $\begin{array}{c}\text { Keveró } \\
\text { átlagos } \\
\text { elöfütési idö } \\
(\text { min.) }\end{array}$ & $\begin{array}{l}\text { Adalék adagolás } \\
\text { sorrendje (min.) }\end{array}$ & $\begin{array}{c}\text { Blendek } \\
\text { átlagos } \\
\text { keverési } \\
\text { ideje (min.) }\end{array}$ \\
\hline Kaucsuk & 168,00 & 168,00 & 168,00 & $10^{\prime}$ & $0^{\prime}$ & $60^{\prime}$ \\
\hline Sztearinsav & & 3,80 & 3,80 & & $10^{\prime}$ & \\
\hline Korom & & 76,00 & 152,00 & & $20^{\prime}$ és $50^{\prime}$ & \\
\hline $\mathrm{ZnO}$ & & 7,60 & 7,60 & & $20^{\prime}$ & \\
\hline ALTAX® & & 0,91 & 0,91 & & $20^{\prime}$ & \\
\hline Kén & & 3,80 & 3,80 & & $35^{\prime}$ & \\
\hline Repceolaj & & 60,00 & 60,00 & & $60^{\prime}$ & \\
\hline
\end{tabular}

Forrás: A szerző saját készítése (2016.)

A keverő motorjának ( 2 tengelyének) fordulatszáma 77 1/min., hőmérséklete 35 $40^{\circ} \mathrm{C}$ között volt az ASTM D3192 szabványnak megfelelően. A rendelkezésemre álló anyagok homogén elegyedéséhez az alappolimert és az adalékanyagokat homogén, képlékeny (plasztikus) állapotba kellett hozni. Ehhez egy ún. „követő” berendezésre volt szükség, amely a megömlesztett állapotban lévő keveréket keveri. $\mathrm{Az}$ ilyen típusú berendezések üzemvitelük szerint megkülönböztethetők, amelyek lehetnek szakaszos és folyamatos üzemvitelüek. Ez esetben egy szakaszosüzemvitelü hengerszékkel volt lehetőség dolgozni, 10\%-os frikcióval. A minták préselésének ideje összesen 30 percet vett igénybe, a préselési hőmérséklet $145^{\circ} \mathrm{C}$, illetve az alkalmazott nyomás 300 bar volt (lásd: 5 . ábra):

\section{5. ábra: A préselt próbatestek}


Forrás: A szerző saját készítésű képe (2016.)

\section{Eredmények és kiértékelésük}

3.1.A préselt próbatestek optikai és analitikai vizsgálata (FT-IR)

$\mathrm{Az}$ infravörös spektroszkópia az egyik leggyakoribb analitikai módszer, amely egy adott vegyület szerkezetének azonosítására, tisztaságának ellenőrzésére szolgál. Ismeretes, hogy a FT-IR berendezések leginkább a próbatestek felületét bombázzák 
az infravörös sugárzással, így a komplett próbatest összetételét kvázi nem képesek adekvát módon meghatározni, hanem a felületen leginkább előforduló vegyület csoportokat (és így a szennyeződéseket is).

Ez esetben a kaucsuk mintára jellemző $\mathrm{C}=\mathrm{H}$ kötéseket, illetve a gumikban adagolt korom spektrumát lehetett csak értékelhető módon megfigyelni. Az egyes mintákról készült FT-IR spektrumokat a 4. számú melléklet tartalmazza, míg az összehasonlításra szolgáló 6. ábra az alábbiakban került feltüntetésre:

\section{6. ábra: A korom, a kaucsuk, a Minta 1. és Minta 2. gumikeverék összehasonlító FT-IR görbéje}

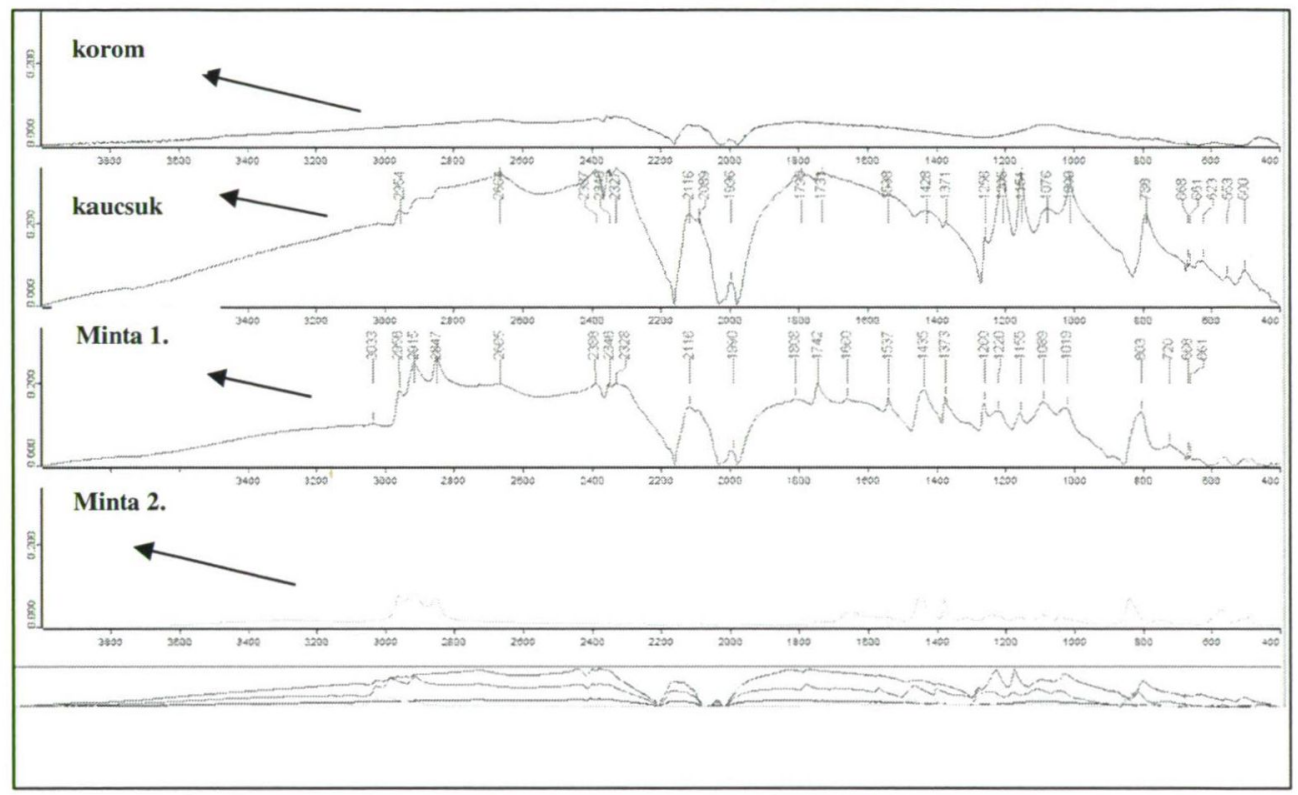

Forrás: A szerző saját eredményei (2017.)

A detektált eredményeket figyelembe véve elmondható, hogy a repceolaj, mint lágyító megfelel a migrációval szembeni elvárásnak, hiszen a felületen nincs a jelenlétére utaló nyom.

\subsection{A préselt próbatestek optikai és analitikai vizsgálata II. (SEM)}

A SEM vizsgálatoknál arra számítottunk, hogy ha homogén az adalékanyagok eloszlása a kaucsukban, akkor nem látni ezek jelenlétét a felületi szennyeződéseken kívül. A feltételezésünk azonban csak részben igazolódott be, ugyanis a Mintal.és Minta2. képein (lásd 7-9. ábra) jól kivehető néhány góc jelenléte, amely az EDS szonda szerint nagyobb mennyiségü ként tartalmaz, ugyanakkor repceolajra utaló nyomokat nem. Így tehát elmondható, hogy az 50 és 350x-es nagyítású felvételeket megfigyelve, a keveredés mégsem volt igazán hatékony. 


\section{7. ábra: A kaucsuk minták 50 és 350-szeres nagyításban}


Forrás: A szerző saját felvételei a Miskolci Egyetem Fémtani és Képlékenyalakítási Intézetében

\section{8. ábra: A Minta 1.50 és 350-szeres nagyításban}

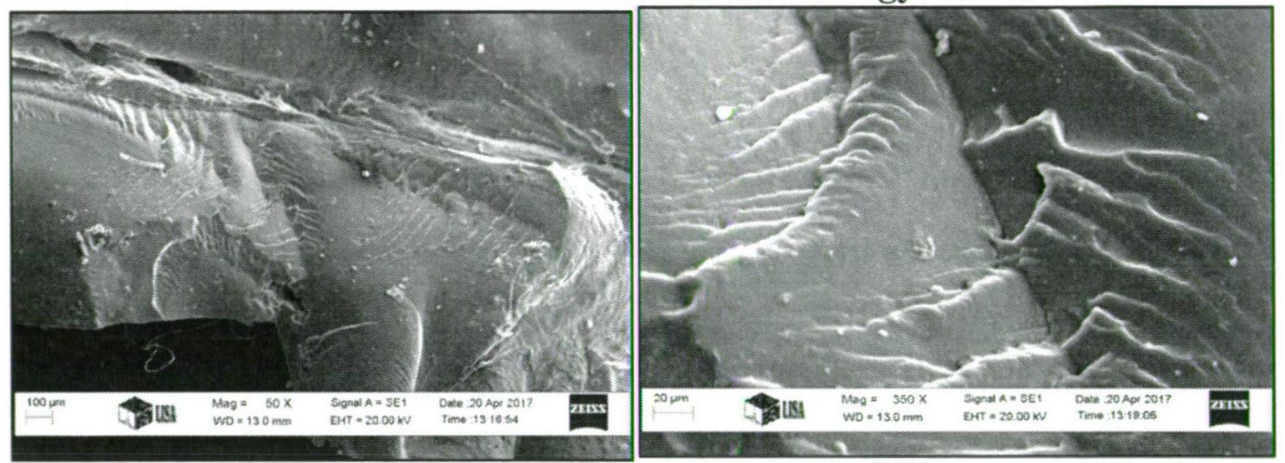

Forrás: A szerző saját felvételei a Miskolci Egyetem Fémtani és Képlékenyalakítási Intézetében

\section{9. ábra: A Minta 2.50-szeres nagyításban, több területről}


Forrás: A szerző saját felvételei a Miskolci Egyetem Fémtani és Képlékenyalakítási Intézetében

A SEM vizsgálathoz kapcsolódóan ellenörzésre került egy EDS szonda által detektált elemi-összetétel meghatározás is, Előnyösebb lett volna, ha az 
alapanyaghoz előzetesen keverek valamilyen követő anyagot (pl. ezüst), amit az elemanalizátor is ki tud mutatni, de a SEM vizsgálatnak elsődleges célja nem annak eredményessége, hanem az adalékanyagok hatásának vizsgálata volt. Az EDS mikroszonda elemanalízisének spektrumán nagyrészt csak a szén $\left({ }_{12} \mathrm{C}\right)$, oxigén $\left({ }_{16} \mathrm{O}\right)$ és kén ${ }_{32} \mathrm{~S}$ ) jelenléte volt tapasztalható, amely a keverékben található adalékanyagok jelenlétére utal.

\section{Következtetések}

Az optikai is felületi vizsgálatok során (FT-IR, SEM) nem volt tapasztalható semmilyen különleges elváltozás, a berendezések által detektált értékek feltételezhetően a felületi szennyeződésekböl származhatnak, illetve a SEM felvételeknél látható néhány, gócra utaló nyom, amely a nem teljesen homogén elkeveredés eredménye lehet. A müszeres kémiai analízisek során megállapításra került, hogy a nemzetközi kémiai jogi szabályozások által tiltott lágyítószerek egyetlen komponensét sem tartalmazták az általunk előállított minták, ezt összefoglalva elmondható, hogy a repceolaj, mint természetazonos lágyítószer kiválóan alkalmas lehet a további felhasználásra, további kiegészítő vizsgálatokkal alátámasztva.

\section{Köszönetnyilvánítás}

Köszönettel tartozom témavezetőmnek, Dr. Zsoldos Gabriellának és a ME Fémtani és Képlékenyalakítási Intézet munkatársainak segítségéért.

\section{Irodalomjegyzék}

Angyal A. (2012): Müanyag és gumi adalékok.

Bartha Z. (1988): Gumiipari kézikönyv I. Taurus-OMIKK, Budapest.

<http://www.tutorvista.com/content/chemistry/chemistry-ii/carboncompounds/natural-rubber.php> (2017. 10. 20.)

Bokor. J. (szerk.). Repceolaj, A Pallas nagy lexikona. Arcanum: FolioNET (1893-1897, 1998.). ISBN 963859232 X. (2017.09. 20.)

Bálint A. (2012): Toxikus vegyületek élelmiszer- és takarmánynövényekben, genetikai lehetőségek a káros hatások csökkentésére. (2017.10.22.)

"Canolaoil, fatcomposition, $100 \mathrm{~g}$ ". US National NutrientDatabase, Release 28, United StatesDepartment of Agriculture. May 2016. (2017.10.15.)

Szakács H. (2012): Müanyag kompozitok. Pannon Egyetem, Veszprém. (2017.10.20.)

Tóth A., Tamási K. (2016): Eltérõ korom összetételü, repceolajjal kevert gumikeverékek mechanikai, termikus, optikai és kémiai vizsgálata. Miskolci Egyetem, Miskolc. 